\title{
Day Times Femtogram per Milliliter
}

National Cancer Institute

\section{Source}

National Cancer Institute. Day Times Femtogram per Milliliter. NCI Thesaurus. Code C85583.

Days times femtograms per milliliter. 